\title{
AN ANALYSIS ON PARADOXICAL GENDER EQUALITY+ POLICIES AND THE VIOLENCE IN BRAZIL
}

Renan de Souza ${ }^{1}$

\begin{abstract}
Brazil records alarming rates of epidemic violence against women and LGBTQ+. According to statistics, the country ranks as the fifth most violent for women and the deadliest in the world for homosexuals. On the other hand, progressive policies to support both groups have been implemented by different public administrations in the last decades generating remarkable milestones. Despite being considered as cutting-edge, those actions have not necessarily translated into a reduction of violence. One explanation for these paradoxes between progressive policies to protect women, LGBTQ+ and the frequent violence against these groups, might be found in historical, cultural, and religious roots. This article highlights that, notwithstanding that some progress was made in Brazil, the rise of conservative and far-right groups may undermine all the advancement reached in the last decades, which could lead to the aggravation of the gender-based violence in the country.
\end{abstract}

KEYWORDS: Women. LGBTQ+. Brazil. Violence. Gender.

\section{UMA ANÁLISE SOBRE O PARADOXO DAS POLITICAS DE IGUALDADE DE GÊNERO+ E A VIOLÊNCIA NO BRASIL}

RESUMO: O Brasil registra dados alarmantes de violência contra as mulheres e LGBTQ+. $O$ pais aparece em estáticas como o quinto mais violento para as mulheres e o mais mortal do mundo para os homossexuais. Por outro lado, politicas progressistas de proteção e apoio aos dois grupos foram adotadas por diferentes governos nas últimas décadas gerando marcos his-

\footnotetext{
1 University of London, London - UK. MA International Relations, Goldsmiths. Orcid: http://orcid.org/00000002-9065-4029 . renan.azuos@gmail.com.
} 
tóricos. Embora consideradas de vanguarda, essas açóes não representaram, necessariamente, uma reduçâo da violência. Uma explicaçâo para esse paradoxo entre politicas progressistas para proteção de mulheres e LGBTQ+ e a constante violência contra esses grupos pode ser encontrada em raizes históricas, culturais e religiosas. O artigo ressalta que, por mais que tenha havido avanços no Brasil, a ascensão de grupos conservadores e de ultradireita no país pode minar todo o progresso atingido nas últimas décadas, o que pode agravar ainda mais a problemática da violência de gênero no país.

PALAVRAS-CHAVE: Mulheres. LGBTQ+. Brasil. Violência. Gênero.

\section{Introduction}

Gender equality+ policies in Brazil are, probably, one of the most controversial in the world. On the one hand, the country has a progressive system and laws to protect women and LGBTQ+. On the other, the nation is the deadliest place in the world for gay people (HM, 2018) and has the planet's fifth-highest femicide rate (ONU BRASIL, 2016). However, one could argue: why are not the laws stopping the violence against women and LGBTQ+ community?

According to the World Health Organization (WHO), Brazil is the deadliest nation in the world for women after El Salvador, Colombia, Guatemala, and Russia. The country has a record of 4.8 homicides per 100 thousand women. In the most recent research, published in August 2018, the Brazilian watchdog Fórum Brasileiro de Segurança Pública ${ }^{2}$ revealed that 606 cases of domestic violence and 164 cases of rape are reported in the country every day. When it comes to the LGBTQ+ population, the situation is not so different in Brazil. The NGO Transgender Europe estimates that 868 transgender people have lost their lives violently in the nation in the period from 2008 to 2016. Four hundred and forty-five homosexuals were murdered in Brazil in 2017. In four and a half years, 1.6 thousand people were assassinated as victims of homophobia and hate crimes in the country, according to the Brazilian watchdog "Gay Bahia Group," responsible for compiling the statistics. On average, this data represents one death per day. In light of the recent political instability, polarisation and division in the country, which resulted in the election of far-right presidential candidate Jair Bolsonaro (known by his inflammatory comments about women

2 Loose Translation: "Brazilian Forum of Public Safety" 
and homosexuals), it is vital to identify the paradox at the heart of the Brazilian state and society regarding women and LGBTQ+.

Therefore, this essay will be structured in three parts to cover these topics. The first unit will analyse the contradictions between the legal system to protect women in Brazil and the violence against them. The following unit is dedicated to a similar approach regarding the LGBTQ+ population in the country. Lastly, the third section will briefly address the rise of far-right groups in Brazil and the danger imposed by this movement to LGBTQ+ and women in a prospective scenario.

\section{Women's right and the violence against them}

Every nine minutes, a woman is raped in Brazil (VIOLÊNCIA..., 2018). Every day, three women are victims of femicide in the country (VIOLENCIA..., 2018). From 2016 to 2017, the rape cases rose by $8.4 \%$. In $2017,4,539$ women were victims of homicides in the country, an increase of $6.1 \%$ compared to the previous year. From this total, 1,133 deaths of women were registered as femicide (FBSP, 2018). In 38 years, the number of women killed in Brazil increased by $252 \%$ (see figure 1 ).

Figure 1 - Women Killed in Brazil: The number of women killed in Brazil increased 252\% from 1980 to 2013

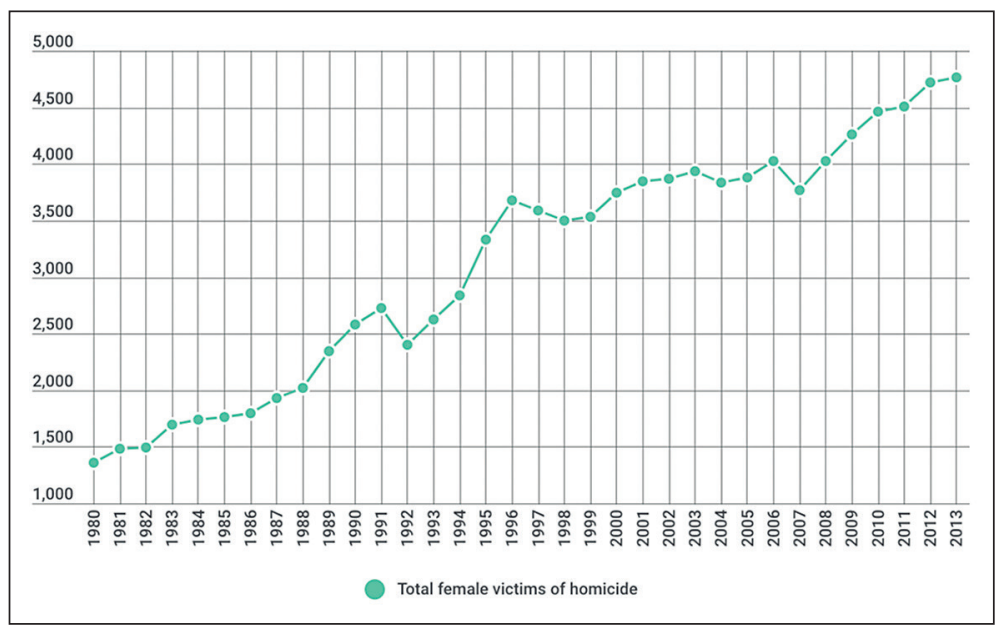

Source: Carless (2015). 
Despite this widespread violence against women, Brazil, until over a decade ago, did not have any specific law to punish and criminalize the violence against women. In 1985, Sao Paulo State was the first Brazilian region to create Woman's Police Stations ${ }^{3}$, a public space dedicated exclusively to support women victims of violence. Those stations are responsible for providing legal and psychological advice, temporary shelter, and medical treatment to victims of violence and sexual aggression. The concept was also expanded and implemented in all other states of the country.

Abroad, the country has signed international treaties such as The Convention on the Elimination of All Forms of Discrimination against Women (CEDAW), adopted by the UN General Assembly in 1979 (THE CONVENTION..., 1979), and the Inter-American Convention on the Prevention, Punishment, and Eradication of Violence against Women (OAS, 1994), also known as the Convention of Belém do Pará. However, after being condemned by the Organization of American States (OAS) for being tolerant and omitted in cases of violence against women, and pressured by human rights and feminist movements, Brazil approved in 2006 the bill named as Maria da Penha ${ }^{4}$, signed by the leftist president Luiz Inácio Lula da Silva. The law "identifies as domestic and family violence against women any action or omission based on gender that causes death, injury, physical, sexual or psychological suffering and moral or property damage" (PAES, 2017). The country also created a special judicial and legal system to prevent the aggressor from contacting a female victim, physically restricting the access by the perpetrator to the victim. This law also offers protection regardless of sexual orientation and has shed light on the issue of violence against women by creating public awareness about this epidemic issue.

The Maria da Penha Law is a local milestone in a struggle against all and any sort of violence and discrimination targeting women. In her article, the author Barbara Paes (2017) details why this law was a meaningful change for women in Brazil:

[...] In 2002, before the existence of the "Maria da Penha" law, a study by the WHO estimated that about $20 \%$ of the women who had been physically assaulted by their husbands in Brazil have remained in silence and did not report the experience - not even to friends and family. A survey

\footnotetext{
3 Loose Translation from Portuguese term Delegacia da Mulher.

4 The Maria da Penha law, number 11.340, sanctioned on 7th August 2006 was named to honour a Brazilian woman who suffered two attempts of murder by her husband, and ultimately, became a prominent figure campaigning to combat the violence against woman.
} 
performed seven years after the enactment of the "Maria da Penha" law, showed a different scenario: that $86 \%$ of the public believes that women should report domestic violence cases to the police. The survey also demonstrated that $98 \%$ of the population has heard of this law and a large portion of the population feels like more women are reporting thanks to the new legislation. [...] (PAES, 2017).

In 2015, Brazil again took a step further, when former president Dilma Rousseff, also from the left-wing, included the femicide in the Brazilian criminal code as well as the discrimination against women. Nevertheless, twelve years after Maria da Penha law was enacted and the system of women's protection was created, homicides against them are still high. Only in 2018, 73 thousand cases of violence against women were reported to the centre for assistance to women in situation of violence (Ministry of Human Rights). In 2016, 12 thousand cases were reported. Although some critics could argue that the violence is not on the rise necessarily -- but there is an increase in the number of cases reported to the police due to the awareness represented by the legislation -- even if this was the case, the high number of reported cases is not compatible or acceptable for a developing county, like Brazil, figuring as the ninth-largest economy in the world (SMITH, 2018).

In an interview addressing the gender-based violence in Brazil, directorpresident of the watchdog Fórum Brasileiro de Segurança Pública Renato Lima said that the "violence against women in Brazil is somehow accepted since it has an element of history" (PAULO; ACAYABA, 2018). Perhaps the history of formation and colonisation of Latin America is, indeed, a key element and a clue to understanding the position of women in the genesis of society. In her findings, Miller (1991) wrote about the beginning of the colonisation period of the region and highlighted that Hispanic and Portuguese women were portraited as primarily as "civilizers". Whereas Indigenous women, girls, and women of African heritage had other roles in society and were deemed as "consorts", "concubines", labours in field, market, and homes. "Colonial society was constructed on distinctions of class, racial heritage, and ethnicity that remain central to an understanding of the history of women in Latin America” (MILLER, 1991, p. 16-17).

Nevertheless, the position of white women in Portuguese America differed from that of her counterparts in Spanish and English-speaking America (LAVRIN, 1978). The ideas brought up by Russell-Wood (1978) are essential to explain the inferiority position of the women in contemporary Brazilian society 
as a heritage from the Portuguese mindset. The root of the problem refers back to the past in colonial Brazil, ruled by the Portuguese Empire (1500-1815).

Male-oriented, male-dominated, patriarchal societies, both ascribed as marginal role to the female, isolating her from mainstream developments in the colony. Anti-feminist and even misogynistic writers from the sixteenth to eighteenth centuries were widely read in Portugal and their work reflected not only on unshakable beliefs in the innate superiority of the male but corresponding disparagement for the female. At first sight, such attitudes appear wholly negative, humiliating the female by relegating her to an inferior position (LAVRIN, 1978, p. 68).

This passage explains the domination and oppression suffered by women in this patriarchal-based society, a model imposed since the beginning of Portuguese America in the sixteenth century. Nearly six centuries later, in Brazil, when a woman tries to get rid of this ancient-oriented misogynistic mindset, she becomes victim of a crime justified "[...] in an argument that women are not fulfilling their roles as mothers, housewives, and spouses because they are working, studying or involved with social networks, among others" (BANDEIRA, 2014, p. 456-457).

As observed in an article by the organisation Human Rights Watch, based on research published by Fórum Brasileiro de Segurança Pública, almost a third of Brazilian women and girls suffered, in 2017, some degree of violence, ranging from threats and beatings to attempted murder. More than half of the attackers were current or former spouses, partners, or acquaintances.

Brazil's colonial background, which has been examined by this essay after revisiting the country's history -- and the comparison of statistics and figures on violence against women -- lead this article to the introduction of the concept of machismo. The term is widely known in Latin America, rarely understood in the countries of the so-called first world and, mostly, rooted in the core of Brazilian society. To better comprehend the term machismo one has to borrow the concept created by Jo Fisher who describes it as "[...] a system of gender relations which exaggerates the differences between man and women according to their so-called 'natural' qualities and determines what is acceptable behaviour from each" (FISHER, 1993, p. 3).

The definition of the concept of machismo comes across with the patriarchal mindset, which deemed women as inferior in the early years of the formation of the Brazilian society. Nevertheless, as this essay has scrutinised, some 
progressive policies were implemented in the Brazilian society aiming to achieve any degree of gender equality and fairness among male and female citizens. However, still the question to be posed is: why are not those laws stopping this violence against women in Brazil? To most Brazilian scholars, the answer may vary. Nonetheless, better training of law enforcement agents and misinterpretation of the Maria da Penha law are pointed out as the main reasons for the problem, especially the misrecognition of the psychological violence, seen as an invisible aggression, and generally deemed as the first step of a potential death of a woman.

According to researcher Maria Cecília Minayo, from Fundação Oswaldo Cruz, "[...] many police officers resist or refuse to register an occurrence, especially in cases of psychological violence, including death threats" (BANDEIRA, 2014, p. 16). Director-president of the watchdog Fórum Brasileiro de Segurança Pública Renato Lima shared similar views saying, "[...] the same way as a police officer is trained to use a firearm in the academy, we, at the forum, are encouraging protocols so that the police officer knows how to deal with a woman who has been a victim of violence [...]" (PAULO; ACAYABA, 2018).

Critically, The Human Rights Watch also endorsed the suggestion of better law enforcement in Brazil as part of measures to stop violence against women in the country and create public awareness about this critical issue. In an article, Maria Laura Canineu, director of the Human Rights Watch Office in Brazil, summarised the situation:

The police don't even take basic investigative steps in many cases when women report violence. They don't take a full statement or have the woman undergo a medical examination. Police stations, even female-staffed stations, lack private rooms to take victims' statements. So even when police are willing to take a statement, women are forced to tell traumatic and humiliating stories in public — and potentially tipping the abuser off that they sought help.

Then, often, police fail to investigate fully, leaving insufficient evidence to support a prosecution. Police often don't take adequate steps to protect victims who do come forward from suffering further abuse. Altogether, women lose faith in the system (CANINEU, 2018). 


\section{The LGBTQ+ rights and the violence against them}

The situation faced by the LGBTQ+ population in Brazil does not differ from its heterosexual women counterparts in the country. Possibly, LGBTQ+ people face an even worst epidemic violence. The danger is imposed by the fact that every 19 hours, an LGBTQ+ person is murdered in Brazil (HM, 2018). Every 48 hours, a person with a transgender identity is killed in the same country (ANTRA, 2018).

These alarming statistics classify Brazil as the world's deadliest place for lesbians, gays, bisexuals, and transgender people (JACOBS, 2016). Four hundred and forty-five homosexuals were murdered in Brazil in 2017, an increase of $30 \%$ compared to 2016. In four and a half years, 1,600 thousand people were killed as victims of homophobia and hate crimes in the country, according to Grupo Gay da Bahia, the watchdog who has been responsible for compiling the statistics for the last 38 years. Those figures are even higher than the 13 countries located in Africa and the Middle East, where the death penalty is applied to homosexuals (HM, 2018).

According to the statistics, this violence is epidemic in Brazil. In 2000, 130 homicides were registered. Ten years later, the figures reached a peak of 260 killings. In 2017, Brazil recorded 445 murders at an all-time highest rate. In ten months, 346 deaths were reported in 2018 (HM, 2018). Those data confirm the trend of increasing and outspread violence against LGBTQ+ people in Brazil, achieving alarming rates and unprecedented rates in the world.

Concerned about the situation, international organisations also have denounced the violence against LGBTQ+ people, hate crimes, and homophobia in Brazil. In 2017, the ILGA - the International Lesbian, Gay, Bisexual, Trans, and Intersex Association, published a report ranking Brazil as the deadliest country for LGBTQ+ in the Americas (PALETTA, 2018).

If we examine the situation through the lens of the transgender victims, the case is even worst. The NGO Transgender Europe estimates that 868 transgender people (see figure 2) lost their lives violently in Brazil during the period from 2008 to 2016 (TGEU, 2016).

According to the Trans Murder Monitoring (TMM) research project, 167 killings of trans and gender-diverse people were registered in Brazil in 2018 (TGEU, 2018) alone. 
Figure 2 - Transgenders Killed in Brazil: 868 trans and gender diverse people murdered in Brazil between January 2008 and June 2016

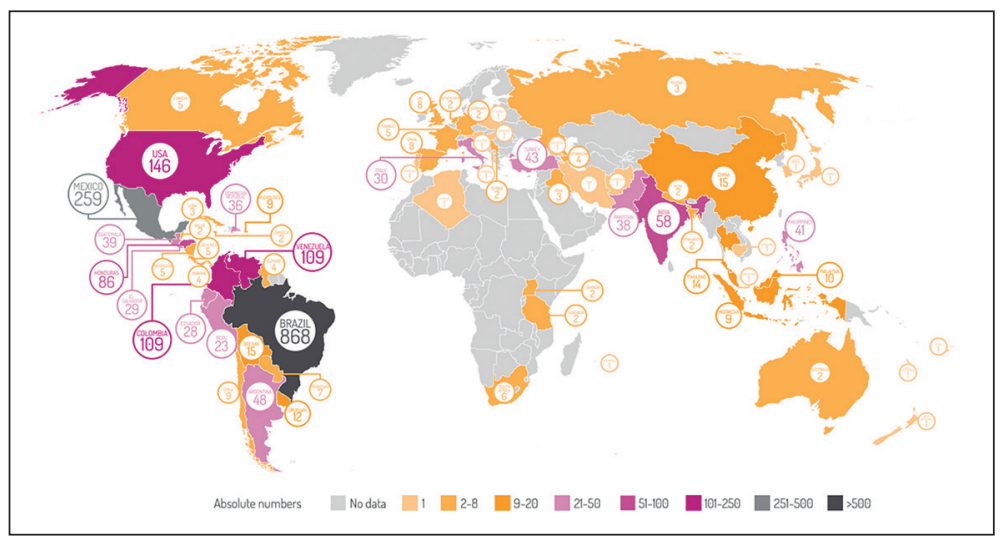

Source: Transgender Europe (TGEU, 2016).

In a space of ten years (from January 2008 to September 2017), Transgender Europe revealed that 2.609 trans and gender-diverse were murdered in 71 monitored countries. In total, 1071 cases were reported in Brazil. Comparing to a cisgender gay man, trans are 14 times more likely to be victims of assassination in Brazil (ANTRA, 2018).

Those data produce a paradoxical view about Brazil, the country which holds, annually, one of the largest Gay Pride parades in the world, attracting more than five million people just in the city of Sao Paulo (USA TODAY, 2019). Regarding the legal protection to the LGBTQ+ community, Brazil has also been quite progressive in this matter since the Imperial Period. In 1830, the new Brazilian Criminal Code was created decriminalizing the concept of sodomy, the most used term until the nineteenth century to define same-sex relationships. (PRETES; VIANNA, 2008). In that period, the Brazilian code was considered progressive in the world, receiving influence from countries such as Spain and France. (PRETES; VIANNA, 2008).

In 1999, the Brazilian Federal Council of Psychology stated that homosexuality is not a "disease", "perversion", or "disturb" (CFP, 1999). Seven years later, as evidenced in the previous chapter, the "Maria da Penha" law was the first federal law to recognize same-sex unions (between women). In 2011, the Brazilian Supreme Court ruled recognizing same-sex -- so-called -- stable unions allowing LGBTQ+ couples to have the same 112 constitutional rights as heterosexual married couples. Two years after this decision, the National Council 
of Justice approved same-sex marriage in the country, converting the previous concept of civil union (BRASIL, 2013). Gay marriage was allowed in Brazil two years before the same decision was ruled in the United States by the Supreme Court.

In Brazil, LGBTQ+ also have their rights guaranteed in matter of legal adoption of children; to serve the military forces openly; right to change their legal gender and use their social names; right to citizenship for their foreigner partner and, beyond that, free access, through the National Health System, to sex reassignment surgery. The polemical conversions therapies are banned in the country (LGBT..., 2018).

At a first glance, Brazil seems to be a paradise on Earth for the LGBTQ+ population. However, the high rates of murders targeting gays, lesbians, and transgender people, as shown before, break any possible idea of a safe haven for this minority in the country. The roots of such violence -- as shown in the previous unit -- in part can, perhaps, be explained by examining Brazil's colonial history.

At that period, sodomy was severally repressed by the Portuguese rulers in the Brazil-colony (PRETES; VIANNA, 2008). Homosexuals were hunted and prosecuted by Inquisitorial Tribunals. The Brazilian anthropologist and historian, Luiz Mott, who wrote about this period, summarises the situation:

[...] There is conclusive evidence that homophobia was most cruel in the populated enclaves of this virgin land. We can see that it was precisely in this primordial formation of the Brazilian people that the roots of our exacerbated contemporary "machismo" infiltrated the national ethos. I believe that the conjunction of two historical factors, one contingent, the other essential, may explain why in the New World, the Iberians became so much stronger in their male chauvinism and our Lusitanian patriarchs even more authoritarian than they were in the Old Continent. [...] (MOTT, 2003, p. 176).

This historical argument corroborates with the suggestions of some scholars, researchers, and human rights activists in Brazil who are vocal about the criminalisation of homophobia to reduce the violent crimes against homosexuals in the country. For over ten years, this law had been discussed in the lower house or the senate (BRASIL, 2017). On 13 June 2019, the Brazilian Supreme Court, eventually, approved the criminalisation of homophobia. Some of the justices 
recognised an institutional delay by the legislative chambers when reviewing the bill (BARIFOUSE, 2019).

In an interview to American newspaper The New York Times, Brazil's former openly gay congressman, Jean Wyllys, who fled the country in January 2019 after receiving death threats (BRAZIL'S..., 2019), had previously blamed the evangelical lawmakers saying they "[...] have stymied legislation that would punish anti-gay discrimination and increase penalties for hate crimes" (JACOBS, 2016).

Christian/Evangelical and reactionary lawmakers are, often, pointed out by scholars as part of the problem in Brazil. At some degree, their conservative discourse combined with the Brazilian culture of machismo are fuelling the hate speech and, ultimately, targeting the lives of LGBTQ+. Addressing the same issue, Jacobs (2016) argues that, for some researchers, the liberal policies have gone too far compared to traditional values, the Brazilian culture of machismo and evangelical Christianity in Brazil, an essentially vast and diverse country.

Apparently, this paradoxical view, which guides this essay, is widely observed around the globe resulting in damage to Brazil's image. Even in a travel advisory to its citizens, the United Kingdom government has said: "Brazil generally has had a tradition of tolerance. However, Brazilian society is quite conservative, particularly outside the larger towns and cities, and LGBT-phobic violence is a concern - you should exercise discretion" (FOREIGN..., 2018).

\section{The Prospective Scenario}

This last unit will briefly explore the future of Brazil regarding gender equality+. In October 2018, the far-right candidate, Jair Bolsonaro, popularly known as the "Trump of the Tropics", was elected as Brazil's president, inaugurating his first term in January 2019.

Bolsonaro carried out an entire politician career based on controversial and offensive comments about women and LGBTQ+ and other minorities. He shouted derogatory phrases against homosexuals such as:

"I won't fight against it nor discriminate, but if I see two men kissing each other on the street, I'll beat them up";

"I'd rather have my son die in a car accident than have him show up dating some guy".

(BRUM, 2018). 
And against women:

"I had four sons, but then I had a moment of weakness, and the fifth was a girl";

"I'm not going to rape you, because you're very ugly", [he said to a female congresswoman].

(BRUM, 2018).

This inflammatory rhetoric against LGBTQ+ and women, combined with lack of support and compromise about the issues described in the previous parts of this essay and no specific law supported by the president to tackle those issues, has been a growing concern to both of these groups in Brazil.

In an interview, LGBTQ+ activist Renan Quinalha said, "[...] the public policies for the LGBT of his [Bolsonaro] government will be hatred, ghettos, and closets. Isolation, indifference, and violence combined to put the LGBT on the margins of society" (PEREIRA JR., 2018).

This same fear is shared by women, who have created an online movement of resistance on Facebook to be vocal against Bolsonaro. The group Mulheres Unidas Contra Bolsonaro (Women United Against Bolsonaro ${ }^{5}$ ) reached 2.5 million members since its creation in August 2018 (see figure 3). As their first rule, only women (cisgender and transgender) are allowed to join in. In September, the founder of this initiative, Ludimilla Teixeira, said to The Guardian newspaper: "[...] it is terrifying to think we might have a president who doesn't care about gender equality, who supports the idea that women should be paid less than men" (PHILLIPS, 2018).

5 Loose translation from Portuguese 
Figure 3 - Women Online Organisation: Facebook Group "Women United Against Bolsonaro"

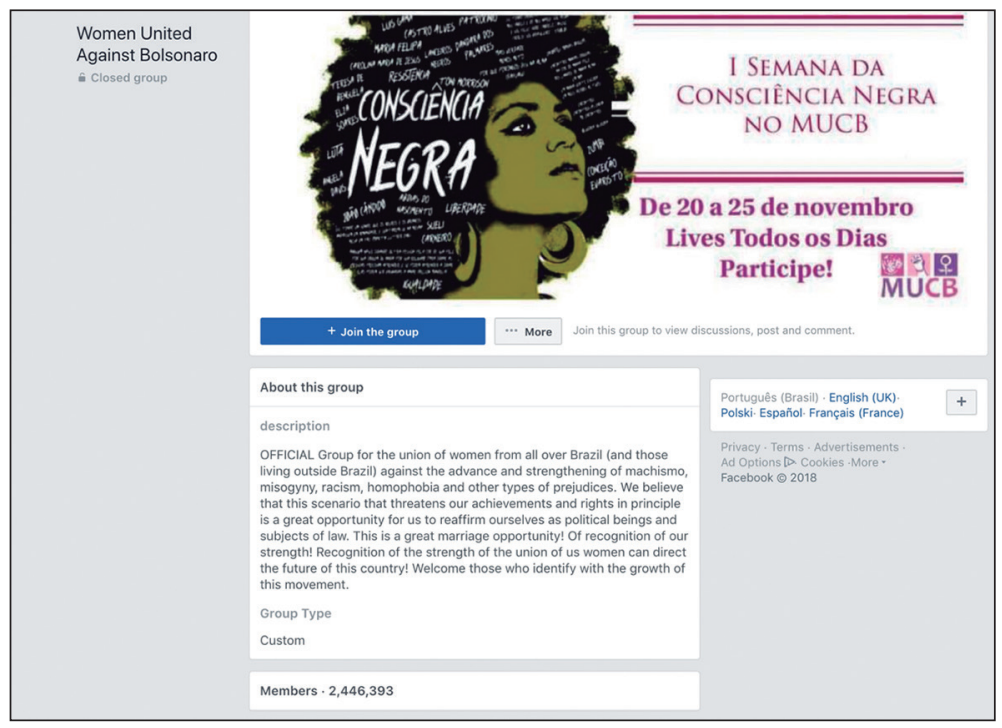

Source: Reproduction-Facebook.

The Women's movement, together with the \#EleNão (\#NotHim ${ }^{6}$ in English) movement, LGBTQ+ activists, and other minorities in Brazil, triggered massive protests in all of Brazil's 27 states and in, at least, 66 cities around the world against Jair Bolsonaro in September 2018. This fact was unprecedented in Brazilian history, and it was considered the biggest ever demonstration organised by women (BRUM, 2018). This historical achievement can be explained by the fact of "[...] the systematic exclusion of women from the process of agendasetting, affords them an opportunity to unite in a broad coalition on the basis of their shared identity" (BALDEZ, 2003, p. 253).

The lack of support from Jair Bolsonaro and his cabinet in tackling gender-based violence is likely to worsen the situation in Brazil in the upcoming years. This circumstance could lead to an increase in deaths of women and LGBTQ+ people, since the conservative Bolsonaro's constituencies may feel confident to expose their prejudice against those groups once there is no formal condemnation of their leader. Bolsonaro's inflammatory rhetoric towards women and LGBTQ+ is a fuel to the rooted machismo culture found in the heart of the Brazilian society.

\footnotetext{
${ }_{6}$ Loose translation from Portuguese
} 
Additionally, the non-commitment of Jair Bolsonaro about the issues brought up by this essay also represents a break of the basic principle of a modern state, which is the protection of its citizens. Epidemic violence in Brazil targeting women and LGBTQ+ is a clear example of what degree the Brazilian state has been failing in protecting its citizens. In this scenario, the division, hatred, and exclusion tend to come about marginalising citizens.

The conservative discourse in Brazil has used the old-fashioned rhetoric from the country's colonial period to target, according to their view, what and who is not confirming with the conservative patterns. As history has shown us, those hatred speeches, nowadays also boosted by the outspread of fake news, tend to end up in assassinations, civil wars, exterminations, divisions, underdevelopment, injustice, and culminate in an endless spiral of violence.

Gender equality+ in Brazil deserves careful attention within the country and also by the international community, multilateral organisations, and watchdog organisms.

\section{Conclusion}

As this essay has shown, the contradictions and dichotomy of women's and LGBTQ+'s rights are part of Brazilian history since the colonial period in the sixteenth century. As some scholars have demonstrated, this is a heritage from the Portuguese colonisation. Five hundred and nineteen years after Brazil was discovered, the culture of machismo in rooted in Brazilian society and at the heart of the state resulting in an epidemic of gender and sexual-based violence

Not even progressive gender equality+ laws were able to stop the violence in the last three decades. Regarding women, Brazil is the fifth most lethal country in the world for them. In this issue, the solution pointed out by scholars and specialists is better training of law enforcer agents to prevent violent crimes, femicide, domestic violence, and any other forms of aggression against women. Moreover, perhaps the solution also can be found in better school education, public campaigns, media, and advertisement to achieve public awareness against the culture of machismo.

The same is applied to the LGBTQ+ population, other victims of this obsolete and archaic way of thinking and interacting inside an organised modern society. From a LGBTQ+ perspective, the recently approved law that criminalises homophobia and hatred crimes could be part of the solution to tackle this issue, as highlighted by some specialists. 
President of Brazil, Jair Bolsonaro, might face strong opposition during his presidency, especially from women's movements, LGBTQ+, and other minorities in Brazil based on his bias and hatred speech. Bearing this in mind, the Brazilian leader should change this rhetoric in order to avoid the aggravation of the gendered and sexual-based violence in the country. Those high crime rates are not acceptable considering the current global mindset and taking into account that Brazil is the ninth-largest economy in the world and it aims to be considered as a developed nation in the future.

\section{REFERENCES}

ASSOCIAÇÃO NACIONAL DE TRAVESTIS E TRANSEXUAIS [ANTRA]. Mapa dos Assassinatos de Travestis e Transexuais no Brasil em 2017. 2018. Available at: https://antrabrasil.files.wordpress.com/2018/02/relatc3b3rio-mapa-dos-assassinatos2017-antra.pdf. Accessed on: 21 Nov. 2018.

BALDEZ, L. Women's movements and democratic transition in Chile, Brazil, East Germany, and Poland. Comparative Politics, New York, v.35, n.3, p.253-272, 2003.

BANDEIRA, L. Violência de gênero: a construção de um campo teórico e de investigação. Sociedade e Estado, Brasília, v.29, n.2, p.449-469, 2014.

BARIFOUSE, R. STF aprova a criminalização da homofobia. BBC News Brasil [online], São Paulo, 2019. Available at: https://www.bbc.com/portuguese/ brasil-47206924. Accessed on: 13 Jun. 2019.

BRASIL. Senado Federal. Criminalizaçáo da homofobia voltará à pauta do Senado em 2018. Brasília: Senado Federal, 2017. Available at: https://www12.senado.leg.br/ noticias/audios/2017/12/criminalizacao-da-homofobia-voltara-a-pauta-do-senadoem-2018. Accessed on: 22 Nov. 2018.

BRASIL. Poder Judiciário. Conselho Nacional de Justiça. Resolução no 175 , de 14 de maio de 2013. Dispóe sobre a habilitação, celebração de casamento civil, ou de conversão de união estável em casamento, entre pessoas do mesmo sexo. Brasília: CNJ, 14 maio 2013. Available at: http://www.cnj.jus.br/images/imprensa/ resolu\%C3\%A7\%C3\%A3o_n_175.pdf. Accessed on: 22 Nov. 2018.

BRAZIL'S sole openly gay congressman leaves country after death threats. The Guardian [online], 2019. Available at: https://www.theguardian.com/world/2019/ jan/24/jean-wyllys-brazils-openly-gay-congressman-leaves-job-country-amid-deaththreats. Accessed on: 24 Jan. 2019. 
BRUM, E. How a homophobic, misogynist, racist 'thing' could be Brazil's next president. The Guardian [online], 2018. Available at: https:/www.theguardian.com/ commentisfree/2018/oct/06/homophobic-mismogynist-racist-brazil-jair-bolsonaro. Accessed on: 22 Nov. 2018.

CANINEU, M. For Brazil's Women, Violence Begins at Home. Human Rights Watch [online], 2018. Available at: https://www.hrw.org/news/2018/01/31/brazilswomen-violence-begins-home\#_ftn2. Accessed on: 19 Nov. 2018.

CARLESS, W. Brazil's shocking violence against women, in five charts. The World [online], 2015. Available at: https://www.pri.org/stories/2015-11-18/brazils-shockingviolence-against-women-five-charts. Accessed on: 23 Nov. 2018.

CONSELHO FEDERAL DE PSICOLOGIA [CFP]. Resoluçáo CFP n 001/99, de 22 de março de 1999. Brasília: CFP, 22 mar. 1999. Available at: http://site.cfp.org. br/wp-content/uploads/1999/03/resolucao1999_1.pdf. Accessed on: 22 Nov. 2018.

FISHER, J. Out of the shadows. London: Latin America Bureau, 1993.

FÓRUM BRASILEIRO DE SEGURANÇA PÚBLICA [FBSP]. Atlas da Violência. 2018. Available at: http://www.forumseguranca.org.br/wp-content/uploads/2018/06/ FBSP_Atlas_da_Violencia_2018_Relatorio.pdf. Accessed on: 23 Nov. 2018.

FOREIGN travel advice: Brazil. Gov.uk [online]. Available at: https://www.gov.uk/ foreign-travel-advice/brazil/local-laws-and-customs. Accessed on: 22 Nov. 2018.

HOMOFOBIAMATA [HM]. Populaçáo LGBT morta no Brasil: relatório 2018. 2018. Available at: https://homofobiamata.files.wordpress.com/2020/02/ relatorio.2018.2docx-2.pdf. Accessed on: 21 Nov. 2018.

JACOBS, A. Brazil is Confronting an Epidemic of Anti-Gay Violence. New York Times [online], 2016. Available at: https://www.nytimes.com/2016/07/06/world/ americas/brazil-anti-gay-violence.html. Accessed on: 21 Nov. 2018.

LAVRIN, A. Latin American women. Westport, Conn.: Greenwood Press, 1978.

LGBT Rights in Brazil. Equaldex [online]. Available at: http://www.equaldex.com/ region/brazil. Accessed on: 22 Nov. 2018.

MILLER, F. Latin American Women and the Search for Social Justice. London: University Press of New England; Hanover, 1991.

MOTT, L. Crypto-Sodomities in Colonial Brazil. Chicago: The University of Chicago Press, 2003. 
ORGANIZATION OF AMERICAN STATES [OAS]. Inter-American Convention On The Prevention, Punishment, And Eradication Of Violence Against Women (Convention Of Belém Do Pará). 1994. Available at: https://www.oas.org/en/ mesecvi/docs/Signatories-Table-EN.pdf. Accessed on: 16 August 2020.

ONU BRASIL. ONU: Taxa de feminicídios no Brasil é quinta maior do mundo; diretrizes nacionais buscam solução. ONU Brasil [online], 2016. Available at: https:// nacoesunidas.org/onu-feminicidio-brasil-quinto-maior-mundo-diretrizes-nacionaisbuscam-solucao/. Accessed on: 23 Nov. 2018.

PAES, B. How is Open Government related to Violence Against Women in Brazil?. Open Government Partnership [online], 2017. Available at: https:/www. opengovpartnership.org/stories/how-is-open-government-related-to-violence-againstwomen-in-brazil/. Accessed on: 18 Nov. 2018.

PALETTA, D. The Americas in 2016: a year marked by significant advances, violence and anti-rights stakeholders. Ilga World [online], 2018. Available at: https:/www. ilga.org/americas-2016-ILGA-State-Sponsored-Homophobia. Accessed on: 21 Nov. 2018 .

PAULO, P. P.; ACAYABA, C. Brasil tem mais de 600 casos de violência doméstica por dia em 2017. G1 [online], 9 ago. 2018. Available at: https:/g1.globo.com/sp/ sao-paulo/noticia/2018/08/09/brasil-tem-mais-de-600-casos-de-violencia-domesticapor-dia-em-2017.ghtml. Accessed on: 19 Nov. 2018.

PEREIRA JR., A. O futuro dos LGBT+ num governo Bolsonaro é viver no medo. Vice [online], 2018. Available at: https://www.vice.com/pt_br/article/pa9wbz/ofuturo-dos-lgbt-num-governo-bolsonaro-e-viver-no-medo. Accessed on: 22 Nov. 2018.

PHILLIPS, T. Stop this disaster': Brazilian women mobilise against 'misogynist' farright Bolsonaro. The Guardian [online], 2018. Available at: https://www.theguardian. $\mathrm{com} /$ world/2018/sep/21/brazilian-women-against-jair-bolosonaro-misogynist-farright-candidate. Accessed on: 22 Nov. 2018.

PRETES, E . A.; VIANNA, T. História da Criminalização da Homossexualidade no Brasil: da sodomia ao homossexualismo. In: LOBATO, W.; SABINO, C.; ABREU, J. F. (org.). Iniciaçáo Científica: destaques 2007. Belo Horizonte: Ed. PUC Minas, 2008. v.1. p. 313-392.

RUSSELL-WOOD, A. Iberian Expansion and the Issue of Black Slavery: Changing Portuguese Attitudes, 1440-1770. The American Historical Review, Cary, v.83, n.1, p.16-42, 1978. 
SMITH, R. The world's biggest economies in 2018. World Economic Forum [online], 2018. Available at: https://www.weforum.org/agenda/2018/04/the-worldsbiggest-economies-in-2018/. Accessed on: 27 Nov. 2019.

TRANSGENDER EUROPE [TGEU]. TMM Update Trans Day of Remembrance 2018. 2018. Available at: https://transrespect.org/en/tmm-update-trans-day-ofremembrance-2018/ Accessed on: 21 Nov. 2018.

TRANSGENDER EUROPE [TGEU]. TMM Annual Report 2016. Berlin: TGEU, 2016. Available at: https://transrespect.org/wp-content/uploads/2016/11/TvT-PSVol14-2016.pdf. Accessed on: 21 Nov. 2018.

THE CONVENTION On The Elimination Of All Forms Of Discrimination Against Women. 1979. Available at: https:/treaties.un.org/doc/Publication/ MTDSG/Volume\%20I/Chapter\%20IV/IV-8.en.pdf. Accessed on: 16 August 2020.

USATODAY.COM. 2019. Pride 2019: The World's 15 Biggest LGBTQ Celebrations, From New York To Tel Aviv. [online] Available at: <https://www. usatoday.com/picture-gallery/travel/2019/06/10/pride-2019-worlds-biggest-lgbtqfestivals/39552479/> [Accessed 16 August 2020].

VIOLÊNCIA contra a mulher em dados. Agência Patrícia Galvão [online]. Available at: https://dossies.agenciapatriciagalvao.org.br/violencia-em-dados/. Accessed on: 23 Nov. 2018.

Recebido em 11 de fevereiro de 2020.

Aprovado em 05 de junho de 2020. 